\title{
THERAPEUTIC IMPORTANCE OF GUMS IN FOLK MEDICINE FROM EASTERN GHATS, ANDHRA PRADESH
} VENKATA RATNAM $\mathrm{K}^{1}$, TIRUPATI REDDY $\mathrm{G}^{2}$, VENKATA RAJU RR ${ }^{3 *}$

${ }^{1}$ Department of Botany, Rayalaseema University, Kurnool, Andhra Pradesh, India. ${ }^{2}$ Department of Biology, Mentor in Biology, IIIT-RK Valley, Rajiv Gandhi University of Knowledge Technologies, Kadapa, Andhra Pradesh, India. ${ }^{3}$ Department of Botany, Sri Krishnadevaraya University, Ananthapuramu, Andhra Pradesh, India. Email: rrvenkataraju@yahoo.com

Received: 26 March 2019, Revised and Accepted: 31 May 2019

\begin{abstract}
Objective: The objective of the present study is to collect ethnobotanical information of gums of medicinal plants from Eastern Ghats of Andhra Pradesh.

Methods: Intensive ethnobotanical field trips were conducted in the forests of Eastern Ghats to collect firsthand information on therapeutic importance of gums used in folk medicine.

Results: The present report deals with the therapeutic importance of gums in folk medicine used by local tribes inhabiting in and around the forests of Eastern Ghats of Andhra Pradesh. The results of the present study revealed that 21 crude drugs belong to 19 genera and 14 families of higher plants. The critical review of literature on crude drugs with reference to that of Eastern Ghats revealed that 13 crude drugs are hitherto not known to the science. 24 herbal formulations are commonly prepared by the local people to cure 14 human ailments. Out of 21 crude drugs reported in the present study, 10 crude drugs have pharmaceutical importance, namely drug delivery agents (Acacia), disintegrate in tablets (Sterculia), thickeners in oral liquids (Acacia and Mangifera), dilutents, binders, gelling agents in gels (Butea, Neem, and Moringa), and protective colloids in suspensions (Anogeissus) and bases in suppository.
\end{abstract}

Conclusion: Natural gums of plant origin have multifarious pharmaceutical applications. In view of the potential crude drugs with promising therapeutic properties used by the tribal people, there is a need to take up the phytochemical and pharmacological investigations.

Keywords: Folk medicine, Gums, Eastern Ghats, Andhra Pradesh.

(C) 2019 The Authors. Published by Innovare Academic Sciences Pvt Ltd. This is an open access article under the CC BY license (http://creativecommons. org/licenses/by/4. 0/) DOI: http://dx.doi.org/10.22159/ajpcr.2019.v12i7.33052

\section{INTRODUCTION}

Excretory products of plant or animal origin do not have well-defined cellular structure. Gums, latex, and oils are the important excretory products of plant origin, which have been used as herbal recipes in ethnomedicine to cure different human as well as veterinary ailments. Gums are translucent and amorphous substances, nonstarch polysaccharides, and soluble in water. The main source of gums is higher land plants, red and brown algae etc. In higher plants, gums are produced by different plant parts such as plant cell wall, stem bark, fruits, seeds, tubers, and roots. Depending on the source of availability, gums are three types, namely (i) plant-derived gums: Depending on the secretion part, plant gums are four types, i.e., stem gums: Produced by exudation from the stem of tree or by tapping method either by accidental or wounds caused by insects' borers (e.g., gum arabic, gum ghatti, and gum karaya); seed gums: Isolated from the endosperm portion of some seeds (e.g., gaur gum and locust bean gum); extracts such as pectin, tubers, and roots gums such as potato starch; (ii) animal origin gums: Example: Chitin and chitosan, chondroitin and hyaluronic acid; and (iii) algal/microbial gums: Gums isolated from marine algae or from microorganisms (e.g., xanthine and dextran) (Choudhary and Pawar, 2014) [1]. Majority of the gums are exuded from the plant stem, only few gums are obtained from roots, leaves, and other parts of the plant. The gum-yielding families are Leguminosae (Fabaceae), Sterculiaceae, Anacardiaceae, Combretaceae, Meliaceae, Rosaceae, and Rutaceae (Goswami and Naik, 2014) [2]. Plant-derived gums are good source of nutraceuticals, pharmaceuticals, as well as calcium, potassium, magnesium, sodium, and phosphorus (Upadhyay, 2017) [3].

Eastern Ghats are a long chain of broken hills and elevated plateaus, running about $1750 \mathrm{~km}$ with an average width of about $100 \mathrm{~km}$ between Mahanadi and Vaigai rivers along the Indian East coast through Odisha, Andhra Pradesh, Telangana, and Tamil Nadu (Narasimhan and Kumar,
2003) [4]. Eastern Ghats in the state are discontinuous range of hills situated between $12^{\circ} 38^{\prime}$ and $22^{\circ} 00^{\prime} \mathrm{N}$ latitudes and $78^{\circ} 50^{\prime}-84^{\circ} 46^{\prime}$ E longitudes (Legris and Homji, 1982) [5]. Ethnobotanically, Eastern Ghats of Andhra Pradesh were well explored by ethnobotanists such as Hemadri, 1981; Raju and Reddy, 1998; Nagalakshmi, 2001; Ram and Raju, 2001; and Reddy. 2008 [6-10], and majority of them were focused on different diseases such as women ailments (Ratnam and Raju, 2005) [11], bone fractures (Ratnam and Raju, 2008) [12], poisonous bites (Saturas et al., 2008) [13], epilepsy (Sandhya et al., 2017) [14], and respiratory disorders (Reddy et al., 2006) [15]. The review of literature on ethnobotany of the study area indicates that no specific report was published on ethnobotanical importance of gums. Hence, the present work is initiated to collect firsthand information on gums from local/ rural people inhabiting in and around the forests of Eastern Ghats of Andhra Pradesh.

\section{MATERIALS AND METHODS}

Intensive plant exploration trips were conducted in the forest areas of Eastern Ghats to record firsthand information form the tribal people residing foreside villages. The information recorded based on the personal interviews with the tribal healers/local Vaidya's who are formulating or advocating the therapeutic uses of plant gums to the local people. The detailed information regarding scientific name, local name, family, part used, mode of preparation/administration, dosimetry, etc., were recorded and systematically analyzed. The plants shown by the tribal people collected and the information was recorded in the field notebook. The collected information was crosschecked with the information from neighboring herbalists and also with available literature. The specimens were identified with the help of local/regional floras (Gamble, 1935; Pullaiah et al., 1995) [16,17] and confirmed by comparing with the authenticated specimens housed at Sri Krishnadevaraya University Herbarium, Anantapur, Madras Herbarium, Coimbatore and Central National Herbarium, Calcutta, Howrah. 


\section{RESULTS AND DISCUSSION}

The present study revealed the ethnobotanical knowledge of gums used by the tribal people of Eastern Ghats of Andhra Pradesh. A total of 21 crude drugs belonging to 19 genera and 14 families were recorded from the study area. The species were enumerated in alphabetical order of scientific name followed by family name, local name, purpose of the use, and mode of administration. The collected crude drug information was cross-checked with available literature (Jain, 1991; Rao and Henry, 1996; and Kirtikar and Basu, 1935) [18-20]. The critical review of literature of the drugs revealed that the information on 13 crude drugs is hitherto not known to the science and the information was depicted in Tables 1 and 2. The family-wise analysis of drugs indicates that Anacardiaceae represented by 3 species followed by Fabaceae, Meliaceae, Combretaceae, and Burseraceae by 2 species each while remaining 9 families represented by single species only.

By analyzing the present folklore information collected from tribes of Eastern Ghats, it was observed that people use different plant parts such as Lawsonia leaves, garlic, asafoetida, mustard seeds, pepper, ginger, and sesame oils and animal products such as honey and goat milk as ingredients along with gums to prepare herbal formulations. The local people use these formulations to cure 14 different human ailments prevailing in the study area. The disease-wise analysis of crude drugs indicates that contraceptive ( 5 species) is the most common disease in the area, followed by menorrhea, dysentery, and ulcers (2 species) and remaining diseases represented by single species each only. The mode of drug administration by the local people revealed that there are 24 herbal formulations, commonly prepared by local people to cure 14 ailments, of which oral administration (13 formulations) is most common use of drugs, followed by external application
(9 formulations). Some drugs used in different mode, for example, gum fumes of Boswellia ovalifoliolata used to cure postnatal complaints and Coccinia grandis gum applied as eye ointment for lacrimation.

Natural gums of plant origin have multifarious applications in pharmaceutical industry as drug delivery agents (Acacia), disintegrate in tablets (Sterculia), thickeners in oral liquids (Acacia and Mangifera), diluents, binders, gelling agents in gels (Butea, Neem, and Moringa), protective colloids in suspensions (Anogeissus), and bases in suppository (Choudhary and Pawar, 2014) [1] and mucilages as clarificants in local jiggery preparation (Chikkappaiah et al., 2017) [21]. The plant gums and latexes are good source of natural antioxidants (Tulasi et al., 2015) [22]. These natural materials have advantages over synthetic medicine as they are chemically inert, non-toxic, less expensive, biodegradable, and widely available. In view of the potential crude drugs with promising therapeutic properties used by the tribal people, there is an urgent need to take up them for the phytochemical and pharmacological investigations.

\section{ACKNOWLEDGMENTS}

Authors are thankful to the authorities of Andhra Pradesh forestry for permission and help during explorations.

\section{AUTHORS' CONTRIBUTION}

$1^{\text {st }}$ and $2^{\text {nd }}$ Authors, Dr. K. Venkata Ratnam and Dr. G, Tirupati Reddy, collected folklore uses of gums from tribal pockets of Eastern Ghats during their doctoral work and prepared MS.

$3^{\text {rd }}$ Author and Corresponding Author: Prof. R.R. Venkata Raju, Research supervisor for both $1^{\text {st }}$ and $2^{\text {nd }}$ authors and helped in MS correction.

Table 1: Systematic enumeration of crude drugs hitherto not known to Science

\begin{tabular}{|c|c|c|c|c|c|}
\hline S. No. & Plant name/family & Local name & Part used & Purpose & Mode of administration \\
\hline 1 & Acacia nilotica/Mimosoideae & Nalla tumma & Gum & $\begin{array}{l}\text { Contraceptive } \\
\text { headache }\end{array}$ & $\begin{array}{l}\text { Gum applied on vaginal track to check } \\
\text { conception } \\
\text { Gum mixed with Lawsonia inermis } \\
\text { leaves, ground, paste applied on forehead }\end{array}$ \\
\hline 2 & Anogeissus latifolia/Combretaceae & Tirumanu & Gum & Menorrhoea & $\begin{array}{l}\text { Gum dissolved in water and given orally } \\
\text { for } 3 \text { days }\end{array}$ \\
\hline 3 & Azadirachta indica/Meliaceae & Vepa & Gum/oil & Contraceptive & $\begin{array}{l}\text { Genital tract is smeared with gum to } \\
\text { check conception (or) one teaspoonful oil } \\
\text { given orally once a day for a week days }\end{array}$ \\
\hline 4 & Bombax ceiba/Malvaceae & Buruga & Gum & Contraceptive & $\begin{array}{l}\text { Gum mixed with honey in equal } \\
\text { proportions and smearing the genital organ } \\
\text { before conjugal union checks conception }\end{array}$ \\
\hline 5 & Boswellia ovalifoliolata/Burseraceae & Kondasambrani & Gum & $\begin{array}{l}\text { Postnatal } \\
\text { complaints }\end{array}$ & $\begin{array}{l}\text { Gum fired, smoke inhaled every day } \\
\text { after } 9 \text { days of delivery }\end{array}$ \\
\hline 6 & Buchanania axillaris/Anacardiaceae & $\begin{array}{l}\text { China } \\
\text { sarapappu }\end{array}$ & Gum & Rheumatism & $\begin{array}{l}\text { Gum mixed with ash, garlic, asafoetida } \\
\text { and made into paste with goat milk and } \\
\text { applied externally }\end{array}$ \\
\hline 7 & Butea monosperma/Fabaceae & Moduga & Gum & Contraceptive & $\begin{array}{l}\text { Gum dissolved in warm water and given } \\
\text { orally for 2-3 days }\end{array}$ \\
\hline 8 & Chukrasia tabularis/Meliaceae & Adavivepa & Gum & Contraceptive & $\begin{array}{l}\text { Gum smeared in the vagina to check } \\
\text { conception }\end{array}$ \\
\hline 9 & Coccinia grandis/Cucurbitaceae & Donda & Gum & Lacrimation & $\begin{array}{l}\text { Fruit gum applied externally as eye } \\
\text { ointment }\end{array}$ \\
\hline 10 & Cochlospermum religiosum/Cochlospermaceae & KondaGogu & Gum & Dysentery & $\begin{array}{l}\text { Gum boiled in water and decoction } \\
\text { given orally for } 2 \text { days }\end{array}$ \\
\hline 11 & Ferula asafoetida/Apiaceae & Inguva & Gum resin & Abortifacient & $\begin{array}{l}\text { Gum resin along with equal parts of } \\
\text { mustard seeds, ground, a teaspoonful } \\
\text { of powder is given orally along with } \\
\text { rice gruel for } 3 \text { days ( } 3 / 4 \text { months old } \\
\text { pregnancy) }\end{array}$ \\
\hline 12 & Mangifera indica/Anacardiaceae & Mamidi & Gum & Leucorrhoea & $\begin{array}{l}\text { Gum along with pepper and ginger ground, } \\
\text { boiled in water, extract given orally }\end{array}$ \\
\hline 13 & Moringa oleifera/Moringaceae & Munaga & Gum & Ear pain & $\begin{array}{l}\text { Gum heated with sesame oil, } 3 \text { to four } \\
\text { drops poured into ears as ear drops }\end{array}$ \\
\hline
\end{tabular}


Table 2: Systematic enumeration of gum crude drugs

\begin{tabular}{|c|c|c|c|c|}
\hline S. No. & Plant name/family & Part used & Purpose & Mode of preparation/administration \\
\hline 1 & Bombax ceiba/Malvaceae & Gum & Menorrhea & Gum dissolved in hot water given orally \\
\hline \multirow[t]{2}{*}{2} & Boswellia serrata/Burseraceae & Gum & Skin eruptions & Fresh gum resin applied externally \\
\hline & & & Ulcers & Gum dissolved in water and given orally \\
\hline 3 & Buchanania lanzan/Anacardiaceae & Gum & Chest pain & Gum as external application \\
\hline 4 & Butea monosperma/Fabaceae & Gum & Antifertility & $\begin{array}{l}\text { Gum dissolved in warm water, given orally once a day for } 1 \\
\text { month to women }\end{array}$ \\
\hline 5 & Diospyros montana/Ebenaceae & Gum & Tuberculosis & Gum dissolved in water, given orally \\
\hline 7 & Pterocarpus marsupium/Fabaceae & Gum & Toothache & Gum as external application \\
\hline 8 & Shoreatumbuggaia/Dipterocarpaceae & Gum & Ulcers & Gum dissolved in water, given orally \\
\hline 9 & Sterculia urens/Sterculiaceae & Gum & Dysentery & Gum dissolved in warm water, given orally \\
\hline 10 & Terminalia bellirica/Combretaceae & Gum & Urinary disorders & Gum dissolved in water, given orally \\
\hline
\end{tabular}

\section{CONFLICTS OF INTERESTS}

The authors do not have conflicts of interests

\section{REFERENCES}

1. Choudhary PD, Pawar HA. Recently investigated natural gums and mucilagesas pharmaceutical excipients: An overview. J Pharm 2014;2014:1-9.

2. Narasimhan KR, Kumar RB. A note on plant and animal interaction from Eastern Ghats. EPTRI-ENVIS News Lett 2003;9:9-10.

3. Hemadri K. Rheumatism: Tribal medicine. Anc Sci Life 1981;1:117-20.

4. Reddy KN, Reddy CS, Trimurthulu G. Ethnobotanical survey on respiratory disorders in Eastern Ghats of Andhra Pradesh, India. Ethnobot Leaf 2006;10:139-48.

5. Jain SK. Dictionary of Indian Folk Medicine and Ethnobotany. New Delhi: Deep Publications; 1991

6. Kirtikar KR, Basu BD. Indian Medicinal Plants. Vol. 4. New Delhi, India: Indian Council of Medical Research; 1935.

7. Rao NR, Henry N. The Ethnobotany of Eastern Ghats in Andhra Pradesh, India. Calcutta: Botanical Survey of India; 1996.

8. Nagalakshmi NV. Studies on Crude Drugs used for Abortion and Antifertility by the Tribals of Rayalaseema, Andhra Pradesh, India. Ph.D. Thesis. Anantapuramu: Sri Krishnadevaraya University; 2001.

9. Ram AJ, Raju RR. Certain potential crude drugs used by tribals of Nallamalais, Andhra Pradesh for skin diseases. Ethnobotany 2001;13:110-5.

10. Legris VM, Homji M. The Eastern Ghats: Vegetation and Bilclimatic Aspects. Proceeding Seminar on Resources Development and Environment in Eastern Ghats. Waltair: Andhra University; 1982. p. $1-7$.

11. Upadhyay RK. Nutritional, therapeutic and pharmaceutical potential of plant gums: A review. Int J Green Pharm 2017;11:30-6.

12. Goswami S, Naik S. Natural gums and its pharmaceutical application. J Sci Innov Res 2014;3:112-21

13. Sandhya S, Hari BM, Suneetha J, Seetharami J, Reddy TV. Ethnomedicine for epilepsy by the tribes of Eastern Ghats, Andhra Pradesh. Med Plant Res 2017:7:19-25.

14. Ratnam KV, Raju RR. Traditional medicine used by the Adivasis of Eastern Ghats for bone fractures. Ethnobot Leaf 2008;12:9-22.

15. Saturas NA, Ratnam KV, Reddy GT, Raju RR. Taxanomic validation of crude drugs used for poisonous bites by Adivasis of Rayalaseema region, Andhra Pradesh. Ethnobot Leaf 2008;12:934-7.

16. Gamble JS. Flora of Presidency of Madras. Vol. 1-3. Calcutta: Botanical Survey of India; 1935

17. Pullaiah T, Chennaiah E, Moulali A. Flora of Andhra Pradesh. Vol. 2. Jodhpur, India: Scientific Publishers; 1997.

18. Ratnam KV, Raju RR. Folk medicine used for common women ailments by Adivasis in Eastern Ghats of Andhra Pradesh. Ind J Tradit Knowl 2005;4:267-70.

19. Raju RR, Reddy RV. Ethnomedicinal Properties of Certain Rare and Interesting Plants from Cuddapah Hills, Andhra Pradesh, Golden Jubilee National Symposium on Spices, Medicinal and Aromatic Plants Biodiversity. Vol. 29. Calicut, India: Conservation and Utilization; 1998. p. 10-2.

20. Reddy KN. Ethnobotany of Andhra Pradesh: A review. Ethnobot Leaf 2008;12:305-10.

21. Chikkappaiah L, Nayaka MA, Mahadevaiah, Kumar GM. Preparation of plant mucilage clarificants and their effect on jiggery processing of sugarcane variety Co 86032. Int J Pharm Pharm Sci 2017;9:32-6.

22. Tulasi CD, Rani AS, Manjula B. Screening of phyto-chemicals, TLC profiling, total flavonoid and phenolics content, anti-oxidant activity and anti-microbial activity of Ficus benghalensis Linn and Ficus religiosa Linn latex. Int J Pharm Pharm Sci 2015;7:480-5. 